\title{
Signet Ring Adenocarcinoma Cell
}

National Cancer Institute

\section{Source}

National Cancer Institute. Signet Ring Adenocarcinoma Cell. NCI Thesaurus. Code

C36777.

A malignant glandular cell containing cytoplasmic mucin. The presence of mucin pushes the nucleus of the cell to the periphery, assuming a configuration resembling a signet ring. 